\title{
CORRECTION TO: FABRICATION OF OPEN-PORE BIODEGRADABLE MAGNESIUM ALLOY SCAFFOLD VIA INFILTRATION TECHNIQUE
}

\author{
Abdurrahim Temiz $(\mathbb{D})$ and Mustafa Yaşar $(\mathbb{1})$ \\ Department of Industrial Design Engineering, Karabuk University, Karabuk, Turkey \\ Erkan Koç@ \\ Department of Biomedical Engineering, Karabuk University, Karabuk, Turkey
}

Copyright $\odot 2021$ American Foundry Society

https://doi.org/10.1007/s40962-021-00616-5

\section{Correction to: \\ International Journal of Metalcasting https://doi.org/10.1007/s40962-021-00604-9}

In the original online version of the article there were errors in Table 1. The original article was corrected.
Publisher's Note Springer Nature remains neutral with regard to jurisdictional claims in published maps and institutional affiliations.

The original article can be found online at https://doi.org/10.1007/ s40962-021-00604-9. 